\title{
Wheat cleaning and milling technologies to reduce DON toxin contamination
}

\author{
${ }^{1}$ Zoltán Magyar $-{ }^{2}$ Antal Véha $-{ }^{1}$ Péter Pepó $-{ }^{2}$ Tibor Bartók $-{ }^{2}$ Ernő Gyimes \\ ${ }^{1}$ University of Debrecen, Kerpely Kálmán Doctoral School, H-4032 Böszörményi road 138. Debrecen, \\ ${ }^{2}$ University of Szeged, Faculty of Engineering, Department of Food Engineering \\ magyarzoltan93@gmail.com
}

\begin{abstract}
SUMMARY
Mycotoxicosis caused by Fusarium fungi holds a huge risk considering economic and food safety issues worldwide. By applying milling technologies, we attempted to reduce the concentrates of DON toxin, as it is the most often found toxin in wheat.

The processes of sieving, aspiration and combination had been used on wheat with high DON toxin concentration. As a next step, grains were sorted using a horizontal cylinder separator, assorted by an optical and a gravity separator, and finally, the products were scoured and ground. The contamination level of the wheat and flour samples were defined by the HPLC-MS method.

Regarding the results, it can be stated that toxin concentration was most effectively reduced by optical separation and scouring, and by applying these milling techniques, food safety can be increased significantly.
\end{abstract}

Keywords: wheat, DON toxin, Fusarium, milling technologies

\section{INTRODUCTION}

Wheat flour is playing a significant role in our daily diet, which is the basic material of many industries, such as bakery, confectionery and pasta industry extending to animal feed as well (Ragasits, 1989).

One of the most frequent diseases of wheat is Fusarium Head Blight (FHB), that is present in almost all regions of the world's wheat growers, which can cause reduction in the quality and yield of wheat production and the contamination of the grains with mycotoxins like deoxynivalenol (DON), zearalenone (ZON), T-2 toxin and fumonisin B1 (Lemmens et al., 2004; Spanic et al., 2018). Trichothecenes (TCT), also called vomitoxins (Peraica, 1999) include T-2, HT-2 and DAS - type "A" TCT-s -, and deoxynivalenol (DON), nivalenol (NIV), FUX - called type "B" TCTs - (Zain, 2011). Trichothecenes can inhibit protein synthesis; can cause extensive necrosis of the oral mucosa and skin on contact; decrease immune functions (Zain, 2011). Lindblad et al. (2013), Draeger et al. (2007) and Mesterházy (2007) said the most important Fusarium toxin in wheat is DON, which is usually produced by Fusarium graminearum and Fusarium culmorum. DON is produced together with derivatives, such as 3-ADON and 15-ADON, and these can be up to $10-20 \%$ of the DON toxin content (Oswald, 2012). Mycotoxins are secondary metabolites produced by fungi (Tzika, 2013), which are responsible for increased risks of many animal diseases and human health problems - also called mycotoxicoses - mainly through the ingestion of food or feed made with contaminated grain (Nelson, 1994), or dermal, inhalation routes (Zain, 2011). Mycotoxins are very resistant to degradation, freezing, pressure, cooking. As a result, they can easily remain in the food chain. The possibility of mycotoxin accumulation in meat, milk and egg because of the contaminated fodder is also a significant threat for the human health (Pal et al., 2015). The grains can be contaminated pre- and pro-harvest, because of improper storage and processing as well in case of improper drying. High humidity and temperature are favourable during the flowering of wheat for Fusarium infection. Moreover, climate change makes it more difficult to lower fungal presence, because of the global heating and the extreme rainfall distribution. In Hungary, the applied mono-cultural agriculture, ploughing of the Fusarium infected plant residues and the lack of regular protection against fungal diseases was also favourable to Fusarium infection (Sohár, 2007).

The strategy for reducing the occurrence of FHB and toxin contamination is possible by cultivation of FHB-resistant varieties, application of effective fungicide treatments, minimization of plant stresses and avoiding lodging. A small number of mycotoxins in cereals is almost unavoidable (Resanovic et al., 2013). According to Rai et al. (2007), 333 winter wheat samples were measured from the 2003-2007 seasons in Lithuania and $88.6 \%$ of the samples were DON positive. In 2005 and 2006, Mesterházy measured more times over $10 \mathrm{mg} \mathrm{kg}^{-1}$ DON contents in Hungary. In a climatically dangered year, from the aspect of the Hungarian economy, the deficit can be tens of billion forints because of Fusarium infection (Mesterházy, 2007).

From the year 2000, notable changes happened in our nutrition habits, since the demand of the high shell content products, for example, whole grain flour, brans and flakes was increased. Owing to the establishment of strict food products regulations like HAACP and the Good Agricultural Practice for mycotoxins, the occurrence of mycotoxins is getting lower, although FAO estimated $25 \%$ of global food crops to be contaminated with mycotoxins, which holds a huge risk all national economies (Pal et al., 2015). Maintaining food safety is a basic human need, therefore, it is essential to examine the cereals' mycotoxin contamination continuously. The problem is that, it is challenging as DON is usually presented 
in minimal quantities, while it generally shows uneven distribution; therefore, the right sampling practice is a very critical step. The EU's limiting value for DON is $1.25 \mathrm{mg} \mathrm{kg}^{-1}$ for wheat, $0.75 \mathrm{mg} \mathrm{kg}^{-1}$ for grist and pasta, $0.5 \mathrm{mg} \mathrm{kg}^{-1}$ for bread (Anonymus, 2006). The TDI value of DON is $1 \mu \mathrm{g} \mathrm{kg}^{-1}$ according to JECFA and SCF (Sohár, 2007). Those batches that exceed the limiting value are not allowed to undergo the milling process. As far as natural FHB infection is concerned in Europe, the highest DON concentration was under $20 \mathrm{mg} \mathrm{kg}^{-1}$, it was $100 \mathrm{mg} \mathrm{kg}^{-1}$ in the USA, but in usual years this value stays well under $0.4-0.6 \mathrm{mg} \mathrm{kg}^{-1}$ DON concentration (Mesterházy, 2007). Using good milling techniques e.g. in preparation for grinding, where qualitative homogenization of the grain batches happens, the DON toxin contamination can be reduced properly. Therefore, an increasing number of mills in Hungary as well - use special operations in their technology. In our experiments, we wanted to examine the toxin-lowering effectiveness of some milling technologies.

\section{MATERIALS AND METHODS}

\section{Materials}

During the experiments, we applied six wheat samples with different levels of DON toxin, which were provided by Cereal Research Non-profit Ltd. The samples were of the same wheat variety from the same area (Mezőhegyes, Hungary). The original DON toxin contaminations can be seen in Table 1. The samples high toxin content is because maize was forecrop in the previous season and the soil was not rotated to provoke Fusarium contamination.

\begin{tabular}{|c|c|}
\hline \multicolumn{2}{|c|}{$\begin{array}{l}\text { Original DON concentration of the combine cleared wheat } \\
\text { samples }\end{array}$} \\
\hline \multicolumn{2}{|c|}{ Samples } \\
\hline Samples' code & $\mathrm{DON}\left(\mathrm{mg} \mathrm{kg}^{-1}\right)$ \\
\hline 214 & 9.9 \\
\hline 23 & 14.2 \\
\hline 210 & 14.5 \\
\hline 26 & 14.6 \\
\hline 24 & 15.2 \\
\hline 29 & 18.3 \\
\hline
\end{tabular}

All devices were provided by the University of Szeged, Faculty of Engineering (Szeged, Hungary) except the optical separator (CHH Technological Ltd., Hungary). In the first experiment, the samples were treated by a sieve, an aspirator and a combinator. After the combinator, a horizontal cylinder-, gravity- and optical separator were used. As a next step, a scourer was used on sorted samples. For grinding the following combinations were used: 1) combinator; 2) combinator + scourer; 3) combinator + optical separator; 4) combinator + optical separator + scourer. The treatments are collected in Figure 1.

DON-toxin measurements were done on the wheat and flour samples that we received from the different operations. It is important to note that all the measurements were done, started with the lowest toxin content moving on the higher ones gradually. The results are mainly dependent on sampling since the DON-toxin distribution is not homogenous. Consequently, we have put a great emphasis on the proper mixing, sampling and purity.

Figure 1: Combinations of the milling technologies in our experiments

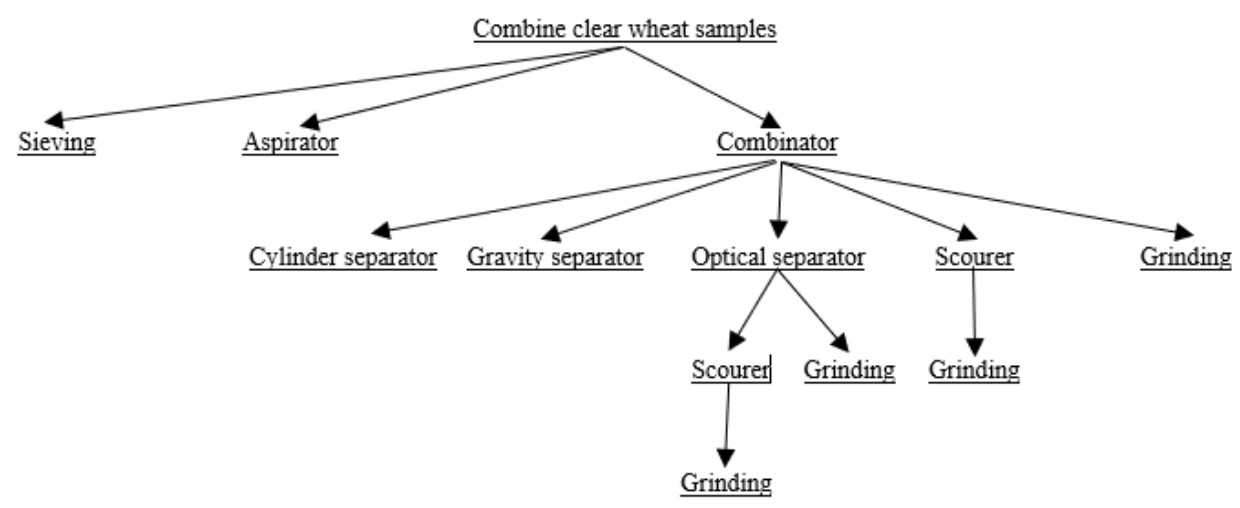

\section{Wheat clearing and milling technologies}

Sieving is the first step of grain-cleaning technology, that is based on the typical size - width and thickness - of the grains. With sieving we can sort out foreign substances and impurities, that is bigger or smaller than wheat grains, such as infected smaller wheat grains, sand, gravel and other grains (Posner and Hibbs, 2011). In this experiment, we applied a 2.2 $\mathrm{mm}$ holed hand sieve.

Aspirating is based on floating rate difference and aerodynamic parameters, where we can sort out the low-density, small particles, like dust, grass, insects, stem and chaff (Biacs et al., 2010). For this procedure, we used the Pfeuffer SLN sample cleaner device 
without sieves. This device's hopper contains a "deawner" part, which separates awn from kernels.

Combinatoring is the combination of sieving and aspiration, where the basis of the separation is the grains' size and aerodynamic properties (Biacs et al., 2010). Combinatoring was done by Pfeuffer SLN sample cleaner, but we put the sieves in. We used three different sieves: 1) $10 \mathrm{~mm}$ round-holed clodsieve; 2) $1.5 \mathrm{~mm}$ round-holed dust-sieve and 3) $2 \mathrm{~mm}$ length-holed grain-sieve.

Broken grains, that are bigger than a half grain cannot be sorted with sieving. Therefore, we used horizontal cylinder separator (Cimbria Heid HSR) (Biacs et al., 2010). First, the inclination angle adjusted so that only the normal kernels fell out of its pockets. The small, broken kernels fell out later, into a bin.

\section{Optical separator}

This separation technique is based on the colour, shape and other optical properties of the grains. Applying a special big resolution camera and LED lighting system, it examines every single wheat grain. The discoloured and Fusarium-infected grains were removed with a sudden compressed air blow. For this experiment, a Cimbria Sea Chrome 3 optical separator device was used, provided by $\mathrm{CHH}$ Technological Ltd. (Hungary). Before the measurement we calibrated the device, so we sorted a few samples by hand - the healthy and infected ones - then inserted them into the device separately more times to register the optical parameters of the separated kernels.

\section{Gravity separator}

The gravity separator is one of the possible final steps of grain-cleaning technology, where the sample is sorted through its specific gravity attribution. The table of the device can be positioned in different foreand-aft $(0-10 \%)$ and transverse $(0-5 \%)$ directions while making a vibrating movement. The table's sieve cloth is fanned by a ventilator from the bottom direction (Biacs et al., 2010). Due to the different density, the components fell in different points of the table, so we could separate the healthy and Fusariuminfected. On the basis of Tibola et al. (2016) experiments, gravity separator was one of the most effective methods to reduce DON toxin. In this case, Cimbria Heid LAB GA type gravity separator was used. We adjusted the fore-and-aft position to $4^{\circ}$, the transverse position to $5^{\circ}$, airflow to $50 \%$ and $100 \%$ for vibration.

\section{Scourer}

According to Ranieri (2011), fungi and their toxins, can be found mostly in bran, therefore, milling technology, intensive surface-cleaning, peeling/scouring reduce contamination even with $50 \%$. It follows that the higher the degree of scouring, the more likely it will decrease the content of the toxin. PeriTec technology's aim is, - which is developed by Satake company - to gradually rubbing off bran of the grains mechanically before further processing (Dexter and Wood, 1996). The scouring was preceded by conditioning from the initial moisture content $(9.9 \%)$ to $15.5 \%$. Conditioning was done with LUX Royal mixing-machine, where we added the water to the sample, and mixed it for 4 minutes, then let it rest for 24 hours in a polyethylene bag. The scouring was done for $10 \mathrm{sec}$ with Satake laboratory rotary-scourer, after this the sample was aspirated with Pfeuffer SLN device to eliminate the scoured materials.

\section{Grinding}

During grinding we relieve the endospermium from the shell parts, and we get flour from endospermium and bran from shell parts. The more the shell parts in the grist, the higher its mineral and vitamin content, but also the concentration of mycotoxin is likely to increase (Lovra, 2011). In grinding process there is no step that eliminates mycotoxin content, but toxin contamination concentrating in fractions like bran and middlings (Cheli et al., 2013). According to Tibola et al. (2015) experiments revealed that using milling solely is not enough to reduce DON in highly contaminated samples. For grinding a Brabender Quadrumat Senior laboratory mill was used. Between the grindings, we ran the device sample-free for 15 minutes to clean the rolls to avoid mixing-up.

\section{Determination of DON toxin contents - HPLC-MS}

Before the toxin measurements, we ground all the samples with Perten 3303 type laboratory disk-grinder at position " 0 " - the lowest one - . Thus, the finest grists were got from them. The homogenized grist samples (1 g from each) were extracted with $6 \mathrm{ml}$ mixture of acetonitrile/water $(84 / 16 \mathrm{v} / \mathrm{v})$ in $10 \mathrm{ml}$ polypropylene centrifuge tubes at room temperature for $15 \mathrm{~min}$, by using an overhead shaker, and centrifuged at $10000 \mathrm{rpm}$ for 10 minutes. After the centrifugation $300 \mu \mathrm{l}$ supernatant was pipetted into polypropylene HPLC sample vial and it was simmered to dry in a centrifugal evaporator at $40^{\circ} \mathrm{C}$. After the evaporation the sample was redissolved with $100 \mu \mathrm{l}$ acetonitrile/water $(84 / 16 \mathrm{v} / \mathrm{v} \%)$ by Vortex test-tube shaker for 5 minutes. Then the samples were put into the HPLC autosampler to analyse DON concentration. The toxin content was measured with HPLC-MS using Agilent Series 1100 liquid chromatograph and an Agilent 1946D mass spectrometer equipped with electrospray ion source.

\section{RESULTS AND DISCUSSION}

\section{Sieving}

The transition and stalling fractions from the 2.2 mm sieve can be seen in Table 2. It can be seen that the DON toxin content (avg. $14.2 \mathrm{mg} \mathrm{kg}^{-1}$ ) is much higher in the stalling fractions than in the transition ones (avg. $27.4 \mathrm{mg} \mathrm{kg}^{-1}$ ). The sieving does not lower the DON content of the transition, but there is a significant difference between the DON contamination of the two fractions. 


\section{Aspiration}

The DON concentrations of the samples are shown in Table 3 after using the aspirator. It showed that the samples' stem and head parts are sorted well by aspiration. Therefore, the DON contaminations were reduced from the starting $14.45 \mathrm{mg} \mathrm{kg}^{-1}$ (average) to $11.06 \mathrm{mg} \mathrm{kg}^{-1}$ (average) value, which means $24 \%$ DON reduction.

Recovery and DON concentrations in sieving fractions

\begin{tabular}{ccccc}
\hline \multicolumn{3}{c}{ Sieving } \\
\hline $\begin{array}{c}\text { Samples' code (starting } \\
\text { DON content mg kg-1) }\end{array}$ & \multicolumn{2}{c}{ Transition fractions (main product) } & \multicolumn{2}{c}{ Stalling fractions } \\
\hline $214(9.9)$ & 89.53 & DON (mg kg-1) & Recovery (\%) & \left.${\text { DON }\left(\mathrm{mg} \mathrm{kg}^{-1}\right)}^{-1}\right)$ \\
$23(14.2)$ & 87.61 & 7.3 & 10.47 & 18.3 \\
$210(14.5)$ & 90.19 & 15.3 & 12.39 & 26.6 \\
$26(14.6)$ & 90.38 & 15.0 & 9.81 & 26.6 \\
$24(15.2)$ & 88.73 & 15.1 & 9.62 & 28.6 \\
$29(18.3)$ & 90.33 & 18.0 & 11.27 & 35.6 \\
\hline
\end{tabular}

Table 3

Recovery and DON concentrations after using the aspirator

\begin{tabular}{cccc}
\hline \multirow{2}{*}{ Sample codes } & $\begin{array}{c}\text { Starting } \\
\text { DON } \\
\left(\mathrm{mg} \mathrm{kg}^{-1}\right)\end{array}$ & \begin{tabular}{c} 
Aspirator's stalling fraction \\
\cline { 2 - 4 }$(\%)$
\end{tabular} & DON $\left(\mathrm{mg} \mathrm{kg}^{-1}\right)$ \\
\hline 214 & 9.9 & 96.98 & 6.8 \\
23 & 14.2 & 95.16 & 12.8 \\
210 & 14.5 & 96.94 & 12.3 \\
26 & 14.6 & 95.38 & 9.1 \\
24 & 15.2 & 95.78 & 11.7 \\
29 & 18.3 & 95.76 & 13.7 \\
\hline
\end{tabular}

\section{Combinator}

In Table 4 the DON concentrations are presented after using combinator by Pfeuffer SLN clearing device. The starting average $14.45 \mathrm{mg} \mathrm{kg}^{-1}$ toxin content was reduced to the avg. $9.43 \mathrm{mg} \mathrm{kg}^{-1}$ (avg. $35 \%$ reduction) with $8-12 \%$ quantity loss by using this procedure. It can be considered as a remarkable achievement that the DON content of the most infected sample (nr 29.) was lowered from $18.3 \mathrm{mg}$ $\mathrm{kg}^{-1}$ to $10.0 \mathrm{mg} \mathrm{kg}$ - only by the application of combinator. 
Concerning toxin content, it can be stated that cylinder separator reduced the $9.3 \mathrm{mg} \mathrm{kg}^{-1}$ avg. starting DON with avg. $1 \mathrm{mg} \mathrm{kg}^{-1}$ (avg. $11 \%$ reduction) with around avg. $2 \%$ volume loss.

Using gravity separator, the DON contamination can be reduced appreciably to avg. $4.3 \mathrm{mg} \mathrm{kg}^{-1}$ (avg. $55 \%$ reduction), however this ends in a notable - avg. $25 \%$ - quantity loss.

The efficiency of the optical separator was even better than of the gravity separator with avg. 75\% toxin reduction. For instance, DON contamination of sample nr. 214 was reduced to $1.2 \mathrm{mg} \mathrm{kg}^{-1}$, which is below the EU's limitation (1.25 $\mathrm{mg} \mathrm{kg}^{-1}$ ), so it can be processed for human consumption as well. However, the quantity loss during the optical separating increased significantly, to avg. $37 \%$.

\section{Scourer}

Scouring time was $10 \mathrm{sec}$ in each treatment. The results of the different cleaning procedures are shown in Table 6 The results of scouring showed high efficiency in DON toxin reductions, which proved by the DON accumulation in wheat bran.

Recovery and DON concentrations after treatments with combinator, scourer, optical separator and their combinations

\begin{tabular}{|c|c|c|c|c|c|c|c|c|}
\hline \multirow{2}{*}{ Samples } & \multicolumn{2}{|c|}{ Combinator } & \multicolumn{2}{|c|}{ Combinator + scourer } & \multicolumn{2}{|c|}{$\begin{array}{c}\text { Combinator + optical } \\
\text { separating main product }\end{array}$} & \multicolumn{2}{|c|}{$\begin{array}{c}\text { Combinator }+ \text { opt. sep. }+ \\
\text { scourer main product }\end{array}$} \\
\hline & Rec. $(\%)$ & $\begin{array}{c}\text { DON } \\
\left(\mathrm{mg} \mathrm{kg}^{-1}\right) \\
\end{array}$ & Rec. $(\%)$ & $\begin{array}{c}\text { DON } \\
\left(\mathrm{mg} \mathrm{kg}^{-1}\right) \\
\end{array}$ & Rec. $(\%)$ & $\begin{array}{c}\text { DON } \\
\left(\mathrm{mg} \mathrm{kg}^{-1}\right) \\
\end{array}$ & Rec. $(\%)$ & $\begin{array}{c}\text { DON } \\
\left(\mathrm{mg} \mathrm{kg}^{-1}\right) \\
\end{array}$ \\
\hline 214 & 100 & 7.1 & 94.49 & 3.4 & 67.76 & 1.2 & 63.83 & 0.8 \\
\hline 23 & 100 & 10.1 & 94.55 & 5.4 & 58.92 & 2.7 & 55.87 & 1.0 \\
\hline 210 & 100 & 9.8 & 94.36 & 6.9 & 68.21 & 1.9 & 64.62 & 1.4 \\
\hline 26 & 100 & 10.1 & 94.19 & 6.6 & 52.22 & 2.9 & 49.11 & 1.1 \\
\hline 24 & 100 & 9.5 & 94.38 & 5.3 & 56.36 & 1.9 & 53.17 & 0.9 \\
\hline 29 & 100 & 10.0 & 94.23 & 4.8 & 75.87 & 3.1 & 72.46 & 1.3 \\
\hline
\end{tabular}

The average starting DON concentration (after combinator), $9.4 \mathrm{mg} \mathrm{kg}^{-1}$ was lowered to average 5.4 $\mathrm{mg} \mathrm{kg}^{-1}$ (with avg. $43 \%$ toxin reduction) by the scourer alone. The combination of combinator, scourer and optical separating together ended in a significant contamination reduction - with and avg. $88 \%$ toxin content elimination -. DON concentrations were below the limitation $\left(1.25 \mathrm{mg} \mathrm{kg}^{-1}\right)$, in 4 out of 6 samples (coded by: 24, 26, 23, 214). Even so, we must consider the increasing quantity losses (avg. 40\%).

\section{Grinding}

In Table 7 the flour yields are detailed. It could be concluded that the flour yield (FY) of the scoured samples' is higher than unscoured ones. This is due to less bran content of the scoured samples.

Flour yields after different combinations of the treatments

\begin{tabular}{ccccc}
\hline \multirow{2}{*}{ Samples } & \multicolumn{4}{c}{ Flour yields (\%) } \\
\cline { 2 - 5 } & $\begin{array}{c}\text { Combinator + grinding } \\
\text { (flour) }\end{array}$ & $\begin{array}{c}\text { Combinator + scourer }+ \\
\text { grinding (flour) }\end{array}$ & $\begin{array}{c}\text { Combinator + opt. sep. + } \\
\text { grinding (flour) }\end{array}$ & $\begin{array}{c}\text { Combinator + opt. sep. + } \\
\text { scourer + grinding (flour) }\end{array}$ \\
\hline 214 & 65.26 & 70.20 & 64.59 & 71.57 \\
23 & 67.78 & 67.63 & 63.07 & 70.53 \\
210 & 63.94 & 67.27 & 66.41 & 69.13 \\
26 & 66.02 & 67.40 & 63.00 & 70.23 \\
24 & 65.32 & 68.50 & 66.00 & 71.43 \\
29 & 63.90 & 68.50 & 65.78 & 70.87 \\
\hline
\end{tabular}

The concentration of DON toxin in the flours are shown in Table 8 The yields are compared to the yields of the combinatored samples, as $100 \%$. The grinding reduced the avg. $9.4 \mathrm{mg} \mathrm{kg}^{-1} \mathrm{DON}$ content to avg. $3.5 \mathrm{mg} \mathrm{kg}^{-1}$ in flours (avg. 63\% DON toxin reduction). Scouring lowered the contamination level usually with avg. $1 \mathrm{mg} \mathrm{kg}^{-1}$. In the case of measuring the flours of combinator and optical separations considering scoured and not scoured as well - the DON contents were under detection level (Figure 2.). It means that the toxin contamination was below the grains' limiting value $\left(0.75 \mathrm{mg} \mathrm{kg}^{-1}\right)$. 
Flours yields and DON concentration after different combinations of milling techniques

\begin{tabular}{|c|c|c|c|c|c|c|c|c|}
\hline \multirow{2}{*}{ Samples } & \multicolumn{2}{|c|}{$\begin{array}{c}\text { Combinator }+ \text { grinding } \\
\text { (flour) }\end{array}$} & \multicolumn{2}{|c|}{$\begin{array}{l}\text { Combinator }+ \text { scourer }+ \\
\text { grinding (flour) }\end{array}$} & \multicolumn{2}{|c|}{$\begin{array}{c}\text { Combinator }+ \text { opt. sep. }+ \\
\text { grinding (flour) }\end{array}$} & \multicolumn{2}{|c|}{$\begin{array}{l}\text { Combinator }+ \text { opt. sep. }+ \\
\text { scourer }+ \text { grinding (flour) }\end{array}$} \\
\hline & $\mathrm{FY}(\%)$ & $\begin{array}{c}\mathrm{DON} \\
\left(\mathrm{mg} \mathrm{kg}^{-1}\right)\end{array}$ & $\mathrm{FY}(\%)$ & $\begin{array}{c}\text { DON } \\
\left(\mathrm{mg} \mathrm{kg}^{-1}\right)\end{array}$ & FY (\%) & $\begin{array}{c}\text { DON } \\
\left(\mathrm{mg} \mathrm{kg}^{-1}\right)\end{array}$ & FY (\%) & $\begin{array}{c}\text { DON } \\
\left(\mathrm{mg} \mathrm{kg}^{-1}\right)\end{array}$ \\
\hline 214 & 65.26 & 2.3 & 66.33 & 2.2 & 43.77 & - & 45.68 & - \\
\hline 23 & 67.78 & 3.8 & 63.95 & 2.2 & 37.17 & - & 39.41 & - \\
\hline 210 & 63.94 & 4.9 & 63.47 & 3.0 & 45.30 & - & 46.61 & - \\
\hline 26 & 66.02 & 3.3 & 63.48 & 2.3 & 32.90 & - & 34.00 & - \\
\hline 24 & 65.32 & 2.9 & 64.65 & 3.0 & 37.20 & - & 37.68 & - \\
\hline 29 & 63.90 & 4.0 & 64.54 & 2.5 & 49.90 & - & 51.76 & - \\
\hline
\end{tabular}

Figure 2: DON concentration after different combinations of milling techniques

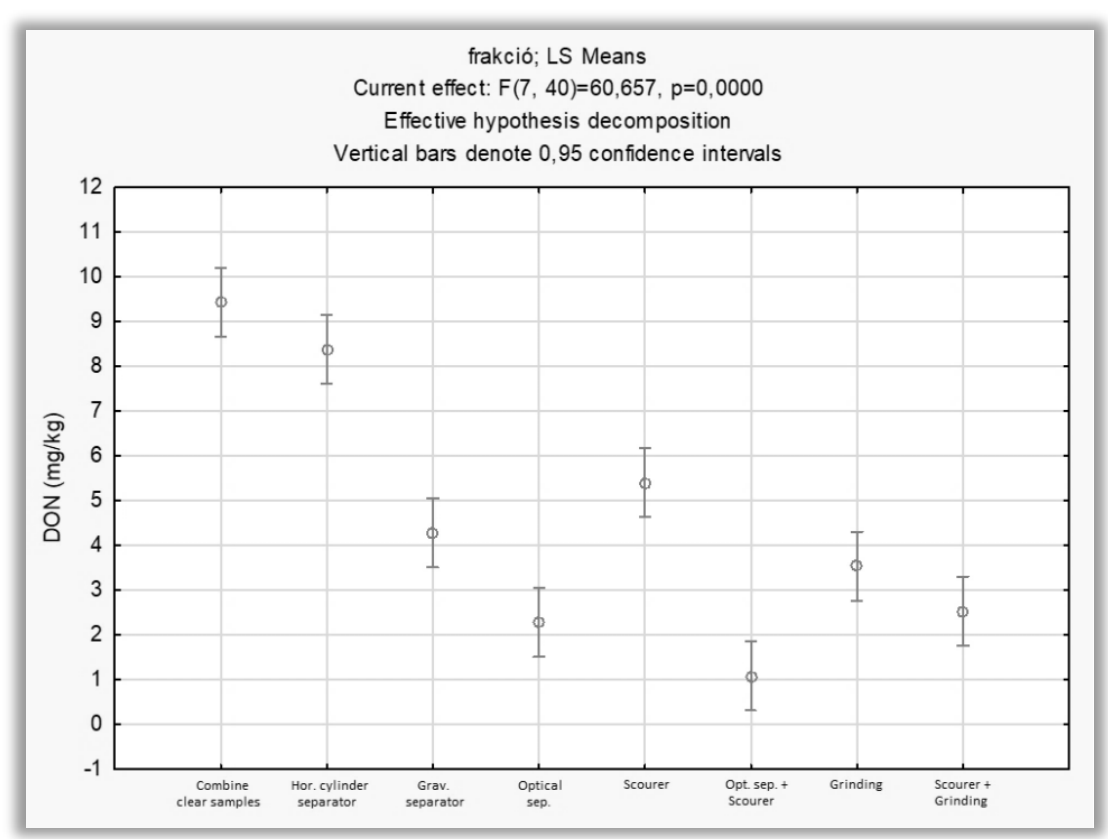

\section{CONCLUSION}

The object of our experiment was to reduce DON toxin contamination of different wheat samples by different milling techniques. At first, the obtained samples were sieved, aspirated and combinatored. The result products were then applied to cylinder-, gravityand optical separator. After that, the combinatored and, -optically purified samples were scoured and ground to flours.

The DON contents of the $2.2 \mathrm{~mm}$ sieve's transition and stalling fractions showed significant differences. The contamination of separated smaller kernels was much higher. This is because Fusarium infection usually results in wizened, smaller kernels. Application of the aspirator device resulted in reduced DON concentration in all samples with an average of $3.5 \mathrm{mg} \mathrm{kg}{ }^{-1}$ value DON (meant a $24 \%$ decrease in DON). The combinator lowered the starting avg. $14.45 \mathrm{mg} \mathrm{kg}^{-1}$ DON to avg. $9.43 \mathrm{mg} \mathrm{kg}^{-1}$ DON (meant a $35 \%$ decrease). It can be stated that we got the smallest yield loss with using horizontal cylinder separator and scourer, however cylinder separating did not reduce DON content significantly (only by an avg. $11 \%$ ), in contrast to scouring (by an avg. 55\%). The average starting DON concentration (after combinator) was $9.4 \mathrm{mg} \mathrm{kg}^{-1}$ and it was lowered to avg. $5.4 \mathrm{mg} \mathrm{kg}^{-1}$ with using only the scourer. Therefore, it can be concluded that scouring is important if we want to ensure food safety. The gravity separator and the optical sorter lowered the DON toxin concentration significantly to an avg. 5.15 $\mathrm{mg} \mathrm{kg}^{-1}(55 \%)$ and to an avg. 7.15 $\mathrm{mg} \mathrm{kg}-1$ (75\%), respectively. The combination of combinator, optical separating and grinding gave the smallest amount of flour yield - $40 \%$ compared to combinatored quantity -, but the DON contents of these samples were under the threshold value, so it is a remarkable result considering the starting contamination levels. Using simply grinding, it reduced toxin contamination strongly with $63 \%$ (to an avg. $3.6 \mathrm{mg} \mathrm{kg}^{-1}$ from an avg. $9.4 \mathrm{mg} \mathrm{kg}^{-1}$ ) with avg. 
$65 \%$ flour yield. Application of only grinding and scourer was not enough to lower the DON content below the limitation $\left(0.75 \mathrm{mg} \mathrm{kg}^{-1}\right)$. Applying scourer before grinding did not decrease flour yields significantly, since by rubbing the shell parts, less bran was made during grinding.
By our results, we can state that the optical sorting and scourer are the most effective ways to reduce DON toxin content, so the application of these procedures in milling technology can increase and ensure food safety even in highly contaminated wheat samples.

\section{REFERENCES}

Anonymus (2006): Commission Regulation (EC) No. 856/2005 of 6 June 2005, Official Journal of European Union 7.6.2005, L $143 / 3$

Biacs, P.-Szabó, G.-Szendrő, P.-Véha, A. (2010): Élelmiszertechnológia mérnököknek, SZTE Mérnöki Kar, Szeged, 28-76.

Cheli, F.-Pinotti, L.-Rossi, L.-Dell'Orto, V. (2013): Effect of milling procedures on mycotoxin distribution in wheat fractions, Food Science and Technology 54, 307-314.

Dexter, J. E.-Wood, P. J. (1996): Recent applications of debranning of wheat before milling, Trends in Food Sci. and Tech. 7: 3541.

Draeger, R.-Gosman, N.-Steed, A.-Chandler, E.-Thomsett, M.Srinivasachary, J.-Schondelmaier, H.-Buerstmayer, M.Lemmens, M.-Schmolke, A.-Mesterhazy, A.-Nicholson, P. (2007): Identification of QTLs for resistance to Fusarium head blight, DON accumulation and associated traits in the winter wheat variety Arina. Theoretical and Applied Genetics 2007, $115,617-625$.

Lemmens, M.-Burstmayr, H.-Krska, R.-Schuhmacher, R.Grausgruber, H.-Ruckenbauer, P. (2004): The effect of inoculation treatment and long-term application of moisture on Fusarium head blight symptoms and deoxynivalenol contamination in wheat grains. European Journal of Plant Pathology 2004, 110, 229-308.

Lindblad, M.-Gidlund, A.-Sulyok, M.-Borjesson, T.-Krska, R.Olsen, M.-Fredlund, E. (2013): Deoxynivalenol and other selected Fusarium toxins in Swedish wheat - Occurrence and correlation to specific Fusarium species. International Journal of Food Microbiology Volume 167, Issue 2, 2013, 284-291.

Lovra Szabolcski, I. (2011): Malomipari Technológia jegyzetfüzet a Mezőgazdasági Iskola diákjainak, Topolya, 46-49.

Mesterházy, Á. (2007): Mikotoxinok a gabonatermesztésben: az élelmiszerbiztonsági kihívás, Élelmiszervizsgálati Közlemények, Élelmiszerminőség-Élelmiszerbiztonság Különszám LIII. kötet, 38-48.

Nelson, P. E.-Dignani, M.-Anaissie, E. J. (1994): Taxonomy, biology, and clinical aspects of Fusarium species. Clinical microbiology reviews. 7. 479-504.
Oswald, I. P. (2012): Animal health, nutrition and mycotoxins, Mycotoxin Symposium, 2012 Quebec

Pal, M.-Gizaw, F.-Abera, F.-Shukla, P. K.-Hazarika, R. A. (2015): Mycotoxins: a growing concern to human and animal health, Beverage and Food World Vol. 42 - No. 5. 42-50.

Peraica, M.-Radic, B.-Lucic, A.-Pavlovic, M. (1999): Toxic effect of mycotoxins in humans, Bulletin of the WHO, 754-766.

Posner, E. S.-Hibbs A. N. (2011): Wheat flour milling, ISBN 1891127-40-3

Ragasits, I. (1998): Búzatermesztés, Mezőgazda Kiadó Budapest, $19-140$.

Rai, M.-Varma, A.-Mankeviciene, A. (2010): Mycotoxins in Food, Feed and Bioweapons, Mycotoxins in Lithuanian Cereals and Grain Products, ISBN 978-3-642-00724-8, 147-163.

Ranieri, R. (2011): Wheat debranning, industrial applications on durum wheat, $6^{\text {th }}$ Annual IAOM Eurasia District, Florence Italy

Resanovic, R. D.-Vucicevic, M. Z.-Nedeljkovic, J. B.-Maslic D. N.-Jacevic, V. M. (2013): Mycotoxins and their effect on human health, Jour. Nat. Sci., Matica Srpska Novi Sad No. 124, 315-324.

Sohár, P-né (2007): Mikotoxinok az élelmiszerláncban, Élelmiszervizsgálati Közlemények, ÉlelmiszerminőségÉlelmiszerbiztonság Különszám LIII. kötet, 60-65.

Spanic, V.-Marcek, T.-Abicic, I.-Sarkanj, B. (2018): Effects of Fusarium Head Blight on Wheat Grain and Malt Infected by Fusarium culmorum, Toxins 2018, Volume 10, 17.

Tibola, C. S.-Fernandes, J. M. C.-Guarienti, E. M. (2015): Distribution of Fusarium mycotoxins in wheat milling process, Food Control 53 (2015), 91-95.

Tibola, C. S.-Fernandes, J. M. C.-Guarienti, E. M. (2016): Effect of cleaning, sorting and milling processes in wheat mycotoxin content, Food Control 60 (2016), 174-179.

Tzika, E. (2013): Impact of mycotoxins on human and animal health, $2^{\text {nd }}$ Foodseg Symposium Bucharest, 2013

Zain, M. E. (2011): Impact of mycotoxins on humans and animals, Journal of Saudi Chemical Society Volume 15, 129-144. 
